\title{
Slovensko v Československu. Otázky sto rokov po vzniku spoločného štátu
}

\author{
Hana Hrancová (Brno)
}

Po prvej svetovej vojne došlo v strednej Európe k územnej reorganizácii - 28. 10. 1918 vyhlásil Národný výbor v Prahe samostatnosť Československa, čím znemožnil vytvorenie pre Čechov neprijatel'nej nemeckej Mitteleuropy a slovenský národ zachránil pred úplnou mad’arizáciou. Slovensko po prvýkrát v dejinách tvorilo samostatný celok s presne stanovenými hranicami. 29. 10. 2018 sa v priestoroch Filozofickej fakulty Univerzity Komenského v Bratislave uskutočnil odborný seminár k 100. výročiu vzniku Československa, organizovaný Univerzitou Komenského v spolupráci s Historickým ústavom Slovenskej akadémie vied.

Po úvodných slovách dekana Filozofickej fakulty Jaroslava Šušola a Gabriely Dudekovej Kováčovej z Historického ústavu SAV otvoril sériu prednášok Dušan Kováč svojím obsiahlym príspevkom s názvom Slovensko medzi tradíciou a modernou, medzi kontinuitou a diskontinuitou. Téma zahrnula široký kontext európskeho sveta na prelome 19. a 20. storočia, ked' sa zrodil nový moderný svet s prvkami typickými pre 20 . storočie, postupne cez jednotlivé etapy až po obdobie prvej Československej republiky. Zaoberal sa otázkou nacionalizmu, ktorý bol najdôležitejšou ideou najmä v 19. storočí, aj vznikom a vývinom česko-slovenskej vzájomnosti, či diferentnými postojmi jednotlivcov ku vzniku Československa.

V príspevku Zápas o mesto Bratislava: Prešporok/Bratislava na konci prvej svetovej vojny a vznik Československa nás Gabriela Dudeková Kováčová previedla nelahkým postavením tohto mesta v jednotlivých dejinných etapách. Slovo „zápas“ v súvislosti s Bratislavou predstavuje zápas vojenský, diplomatický, ale aj symbolický, pretože boj o to, ktoré etnikum mestu dominuje a komu patrí, už tu bol odpradávna. Prešporok bol často považovaný aj za mad’arské mesto a koncom prvej svetovej vojny sa šírila teória, že spojenie s Československom by toto mesto zahubilo, no napriek tomu sa tak podla demarkačnej línie stalo a Bratislava zostala naším hlavným mestom. Čast' svojej prednášky venovala autorka aj rozboru názvu tohto mesta, ktoré sa neoficiálne, najmä na pohladniciach československých légií, nazývalo aj Wilsonovo mesto.

Sériu prednášok o meste Bratislava uzatvoril Jozef Tancer, hovoriac o jazykovej situácii v Bratislave po vzniku prvej Československej republiky. Tá nebola jednoduchá nikde na Slovensku a obzvlášt v Bratislave, v meste ležiacom na hranici troch štátov. Tancer rozprával o trojjazyčnej Bratislave, pričom toto slovko „trojjazyčná“ v nás môže evokovat’ to, že obyvatelia rozprávali troma jazykmi, čo však nie je pravda. Ako tvrdí, aj na základe vlastných výskumov, väčšina Bratislavčanov hovorila jedným, nanajvýš dvoma jazykmi v závislosti od prostredia, v ktorom sa pohybovali. Okrem spisovných jazykov sa v Bratislave viac používali rôzne dialekty nemčiny, ale aj mad’arčiny.

Poobedňajšia sekcia prednášok sa niesla v duchu témy očakávaní a predstáv verzus realita a mýty, popr. kontramýty o Československu. Ludovít Hallon, ktorý sa venuje hospodárskym dejinám, sa predstavil s prednáškou o plusoch a mínusoch hospodárskeho vývoja Slovenska v troch režimoch (habsburská monarchia, medzivojnová ČSR, slovenský štát 1939-1945). Roman Holec sa zamýšlal priamo nad otázkou, čo to vlastne mýtus je a či bola demokracia v Československu mýtom. Dotkol sa aj hospodárskej oblasti a rozvinutosti Československa, pretože aj tvrdenie, že ČSR bola 10. najrozvinutejšou krajinou, je podla jeho slov mýtus. Záverečná téma Koncept Československa ako národného 
štátu - predstavy a realita, ktorá sa venovala siene Filozofickej fakulty Univerzity Komenskétomu, ako v skutočnosti vyzeralo Českosloven- ho. Budova filozofickej fakulty bola v minulosti sko, na rozdiel od toho, aké boli predstavy, jednou z vládnych budov. Sídlilo v nej napríklad patrila historikovi zaoberajúcemu sa prevažne aj vojenské velitel’stvo rakúsko-uhorskej cisárskej modernými dejinami 20. storočia, Janovi Rych- královskej armády a neskôr aj Vavro Šrobár ako líkovi. minister s plnou mocou pre správu Slovenska.

Konferencia s mimoriadnym vedeckým zastúpením českých a slovenských vedcov sa konala $\mathrm{v}$ reprezentatívnych priestoroch Moyzesovej bola na záver podujatia odhalená.

\section{Mgr. Hana Hrancová}

Ústav slavistiky

Filozofická fakulta, Masarykova univerzita

Arna Nováka 1, 60200 Brno, Česká republika

450832@mail.muni.cz 